\title{
Pengaruh Penerapan E-Filling Terhadap Kepatuhan Wajib Pajak Orang Pribadi
}

\author{
Ni Komang Cahyani Purnaningsih ${ }^{1}$ \\ Fakultas Ekonomi dan Bisnis Universitas \\ Udayana, Indonesia. \\ Email: cahyanitatik11@gmail.com
}

\author{
Naniek Noviari ${ }^{2}$ \\ Fakultas Ekonomi dan Bisnis \\ Universitas Udayana, \\ Indonesia.
}

\begin{abstract}
ABSTRAK
Perkembangan teknologi yang semakin canggih kini memudahkan manusia untuk melakukan berbagai pekerjaan. Tujuan penelitian ini adalah untuk mengetahui tingkat kepatuhan wajib pajak orang pribadi yang dipengaruhi oleh penerapan e-filling di KPP Pratama Gianyar. Metode analisis data menggunakan analisis jalur (path analysis). Data penelitian menggunakan data primer yaitu jawaban wajib pajak orang pribadi yang terdaftar di KPP Pratama Gianyar atas kuesioner yang diberikan. Hasil penelitian ini menunjukkan bahwa ekspektasi usaha dan pengetahuan yang dimiliki oleh pengguna memiliki pengaruh positif pada kepatuhan pengguna. Keamanan dan kerahasiaan data, kecepatan pelaporan memiliki pengaruh positif pada minat penggunaan $e$-filling.
\end{abstract}

Kata Kunci: $\quad$ E-Filling, kepatuhan, pengetahuan, keamanan, kerahasiaan.

\section{Effects of E-Filing Application on Personal Taxpayer Compliance}

\section{ABSTRACT}

The development of increasingly sophisticated technology now makes it easier for humans to do various jobs. The purpose of this study was to determine the level of individual taxpayer compliance that was influenced by the application of e-filling at KPP Pratama Gianyar. The method of data analysis uses path analysis. The research data uses primary data, namely the answers of individual taxpayers registered at KPP Pratama Gianyar for the questionnaire given. The results of this study indicate that business expectations and knowledge possessed by users have a positive influence on user compliance. Security and confidentiality of data, the speed of reporting has a positive influence on interest in using e-filling.

Keywords :

$$
\begin{aligned}
& \text { E-Filling, compliance, knowledge, } \\
& \text { security, confidentiality. }
\end{aligned}
$$

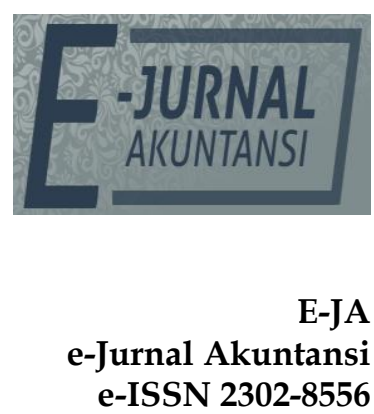

Denpasar,

Vol. 28 No. 3

September 2019

Hal. 1838-1854

Artikel masuk:

24 Mei 2019

Tanggal diterima: 11 Juni 2019 


\section{PENDAHULUAN}

Pajak sebagai salah satu hal penting yang berfungsi sebagai penerimaan jangka panjang negara serta untuk retribusi kesejahteraan masyarakat. Akan tetapi, peraturan yang berlaku tidak serta merta menganggap bahwa pelaksanakan perpajakan akan dipatuhi oleh seluruh lapisan masyarakat. Pajak memberikan kontribusi bagi negara untuk mengurangi defisit dan meminimalkan pinjaman ke luar negeri (Tene, dkk., 2017). Pendapatan pajak adalah sumber daya yang kuat untuk mendanai pembayaran publik negara maju, berkembang dan terbelakang di dunia. Namun besarnya pendapatan yangdihasilkan oleh pemerintah dari pajak untuk program pengeluarannya tergantung pada kemauan wajib pajak untuk mematuhi hukum pajak suatu negara (Deyganto, 2018).

Kepatuhan wajib pajak menunjukkan tingkat patuhnya atau gagalnya wajib pajak untuk patuh terhadap peraturan mengenai perpajakan di setiap negara. Pajak merupakan sumber penerimaan negara yang sangat mendominasi pendapatan negara, hal ini sangat masuk akal mengingat jumlah penduduk di suatu negara yang selalu meningkat setiap tahunnya (Handoyo \& Candrapuspa, 2017). Penerimaan pajak digunakan oleh negara untuk membiayai segala kebutuhan negara, hal inilah yang membuat pemerintah terus berusaha untuk meningkatkan penerimaan dari pajak dengan meningkatkan tingkat kepatuhan pajak bagi wajib Kepatuhan pajak dapat tercapai dan berjalan sesuai yang diharapkan pemerintah apabila sistem perpajakan diberikan pengawasan secara ketat dan disediakan sanksi yang cukup bagi yang ternyata terbukti melakukan pelanggaran perpajakan (Manual \& Xin, 2016).

Kepatuhan pajak diartikan sebagai perilaku memenuhi kewajiban pajak oleh wajib pajak serta memperoleh hak perpajakan sesuai dengan peraturan yang berlaku (Marjan, 2014). Pemanfaatan pajak untuk meningkatkan penerimaan negara akan berhasil apabila setiap wajib pajak sadar akan pentingnya membayar pajak dan patuh terhadap aturan yang ditetapkan. Kepatuhan perpajakan dapat dinilai dari berbagai hal, dimulai dari memberikan informasi sebenarnya terkait usaha yang dimiliki wajib pajak, serta melaporkan perkembangan usahanya. Penerimaan pajak maksimal dapat dicapai pemerintah dengan berupaya meningkatkan kepatuhan wajib pajak dan membuat ketentuan pajak yang dapat diterima oleh setiap wajib pajak, dengan tanpa merugikan salah satu pihak manapun.

Tingkat kepatuhan wajib pajak tampaknya masih menjadi masalah utama rendahnya penerimaan negara dari pajak. Kondisi kepatuhan wajib pajak di KPP Pratama Gianyar diperlihatkan pada Tabel 1 berikut.

Tabel 1. Tingkat Kepatuhan Wajib Pajak Orang Pribadi yang Terdaftar di KPP Pratama Gianyar Tahun 2014-2017

\begin{tabular}{lcccc}
\hline & \multicolumn{4}{c}{ Tahun } \\
\cline { 2 - 5 } \multicolumn{1}{c}{ Uraian } & 2014 & 2015 & 2016 & 2017 \\
\hline Total WPOP Terdaftar & 92.759 & 103.143 & 114.677 & 125.113 \\
WPOP yang Wajib & 92.161 & 102.125 & 113.599 & 123.797 \\
Menyampaikan SPT & & & & \\
\hline Bersambung ... & & &
\end{tabular}




\begin{tabular}{lcccc} 
Lanjutan Tabel 1. & & & \\
\hline Total Realisasi WPOP yang & 53.527 & 56.859 & 66.221 & 61.373 \\
$\begin{array}{l}\text { Menyampaikan SPT } \\
\text { WPOP yang }\end{array}$ & 53.479 & 56.764 & 65.468 & 16.557 \\
$\begin{array}{l}\text { Menyampaikan SPT Secara } \\
\text { Manual }\end{array}$ & & & & \\
$\begin{array}{l}\text { WPOP yang } \\
\text { Menyampaikan SPT dengan }\end{array}$ & 3746 & 749 & 44.709 & 52.077 \\
$\begin{array}{l}\text { E - Filling } \\
\text { Tingkat Kepatuhan WPOP }\end{array}$ & $62,92 \%$ & $56,32 \%$ & $96,98 \%$ & $55,44 \%$ \\
\hline
\end{tabular}

Sumber: KPP Pratama Gianyar, 2019

Kepatuhan wajib pajak pada masing-masing KPP dikatakan cukup baik apabila berada pada persentase $72,5 \%$. Tingkat kepatuhan juga dapat dilihat dari persentase jumlah pemberitahuan tahunan (SPT) yang terdaftar dari wajib pajak (Mahestyanti, et al., 2018).

Berdasarkan tabel tersebut terlihat bahwa tingkat kepatuhan wajib pajak justru mengalami penurunan. Total realisasi Wajib Pajak Orang Pribadi yang melaporkan SPT juga mengalami penurunan di tahun 2017. Ditambah lagi, jumlah WPOP yang mengunakan sistem e-filling masih tergolong sedikit. Hal ini menunjukkan bahwa perlu dilakukannya penelitian akan penerapan e-filling di KPP Pratama Gianyar. Ada beberapa asalan yang menjadi penyebab WPOP enggan melaporkan pajak dengan cara yang manual, diantaranya waktu pengisian yang dirasa tidak cukup, dan rumitnya pengisian secara manual yang membuat wajib pajak merasa kesulitan.

E-filling merupakan salah satu terobosan baru yang dilakukan oleh Direktorat Jenderal Pajak (DJP) untuk memudahkan wajib pajak dalam melaporkan kewajiban perpajakannya, yang pada akhirnya akan meningkatkan penerimaan pajak negara. Hal ini dirancang sebaik mungkin dengan tujuan untuk memudahkan WPOP dalam memberikan laporan SPT. Adanya sistem $e$-filling ini bertujuan untuk meningkatkan kesadaran dan memudahkan wajib pajak untuk melakukan kewajibannya (Noviandini, 2012).

Adanya kemudahan dari penerapan e-filling ternyata tetap memiliki hambatan-hambatan. Sistem pajak online ini bermasalah pada koneksi internet yang masih lambat dan tidak jarang mengalami eror, sehingga berdampak pada lamanya proses pengisian laporan. Hambatan utama dalam penerapan sistem ini adalah masih kurangnya wawasan wajib pajak terakit tata cara penggunaan $e$ filling, yang berakibat pada kurang optimalnya penggunaaan sistem tersebut. Kendala lain yang cukup serius adalah wajib pajak tak jarang melupakan username dan password yang digunakan untuk mengakses bagian databaseperpajakan milikinya. Kendala-kendala tersebut kemudian menjadi faktor pendorong masih kurangnya penggunaan e-filling bagi wajib pajak.

Penelitian ini memberikan bukti empiris mengenai penerapan e-filling yang mengacu pada model UTAUT, yakni sebuah model yang dikembangkan oleh Morris, et al., (2003) Unified Theory of Acceptance and Use of Technologi atau UTAUT ini bertujuan untuk mengidentifikasi dengan mudah faktor yang mendorong penerapan $e$-filling. Model UTAUT memberikan gambaran mengenai empat faktor yang mampu mendorong penerapan e-filling, diantaranya perkiraan kinerja, 
perkiraan usaha, faktor sosial dan kondisi. Model ini memberikan kepercayaan kepada wajib pajak mengenai manfaat penggunaan e-filling untuk meningkatkan kinerja dan mengurangi waktu yang diperlukan, serta bagaimana implementasi $e$ filling dipengaruhi oleh faktor lingkungan, serta sarana dan prasarana.

Minat penggunaan e-filling bagi wajib pajak dapat didorong oleh ekspektasi usahanya di masa mendatang. Wajib pajak yang memiliki keyakinan bahwa sistem e-filling dapat membantu penyelesaian pekerjaannya, maka akan terdorong keinginannya untuk menerapkan sistem ini. Pengguna yang memiliki pengetahuan yang cukup terkait ketentuan perpajakan, dan kemampuan dalam mengoperasikan e-filling akan meningkatkan minat wajib pajak dalam melaporkan kewajibannya. Keamanan dan kerahasiaan data menjadi hal yang penting saat ini. Wajib pajak akan terdorong untuk menggunakan sistem yang mampu menjamin kerahasiaan data yang mereka miliki. Kecepatan akses juga menjadi hal yang krusial, dimana akses yang cepat mendorong wajib pajak menggunakan $e$-filling.

Kesadaran wajib pajak merupakan hal utama dalam upaya untuk menarik minat pelaporan pajak. Kesadaran menyangkut keinginan dari dalam diri wajib pajak untuk ingat terhadap kewajibannya. Semakin sadar wajib pajak pada kewajibannya, maka semakin tinggi tingkat kepatuhan wajib pajak. Kualitas layanan juga faktor penting dalam memengaruhi minat wajib pajak. Kegiatan untuk menciptakan kenyamanan dan memberikan berbagai kemudahan kepada masyarakat merupakan definisi dari peningkatan kualitas layanan menurut (Komala, dkk., 2014). Keinginan wajib pajak untuk menunaikan kewajiban pajaknya mayoritas dipengaruhi oleh layanan yang disediakan oleh pemerintah. Kualitas dan kuantitas layanan yang terbaik mampu meningkatkan minat wajib pajak untuk patuh terhadap pelaporan pajak (Mareta, dkk., 2014). Pengetahuan dasar terkait perpajakan sangat bermanfaat dalam membantu wajib pajak menyelesaikan kewajibannya (Febrianti, 2014). Pengetahuan tersebut akan memberikan gambaran wajib pajak pada sanksi yang dapat diterima apabila tidak mematuhinya (Ramayah, 2010). Sanksi yang dapat diterima apabila tidak mematuhi ketentuan menjadi hal penting untuk memastikan wajib pajak melakukannya dengan baik dan sesuai aturan.

Handayani, (2007) melakukan penelitian terkait empat variabel dalam model UTAUT. Hasil yang diperoleh adalah keempat faktor dalam model memberikan pengaruh positif pada keinginan wajib pajak untuk memanfaatkan sistem yang ada. Namun hal ini justru berbanding terbalik yakni keinginan tersebut tidak mendorong pada penggunaannya. Penggunaan sistem oleh wajib pajak justru dipengaruhi secara signifikan oleh tingkat kesulitan dalam mengoperasikannya (Wiyono, 2008).

Penelitian inimembantu dalam memberikan solusi mengenai masalahmasalah yang diakibatkan karena penerapan sistem e-filling. UTAUT juga mencakup aspek karakteristik pengguna, serta beberapa kondisi yang berlaku pada saat adopsi dan kemungkinan penggunaan teknologi, sistem atau layanan (Mukisa \& Ochieng, 2013). Prediksi dari ekspektasi kinerja adalahdimediasi oleh usia, jenis kelamin dan pengalaman (Attuquayefio, 2014).

E-filing merupakan sistem pengirimian dokumen pajak secara online dari wajib pajak kepada departemen pajak melalui koneksi internet, tanpa memerlukan dokumen dalam bentuk kertas. Berbagai perangkat lunak persiapan 
pengembalian pajak dengan kapabilitas e-filling tersedia sebagai penggunaan komersial mandiri (Muthulakshmi, 2019). Electronic Tax filing (ETF) atau sistem pengarsipan pajak serupa sebagai cabang aplikasi e-government secara luas diadopsi di seluruh dunia. Karena signifikansinya, Penghasilan dan Penjualan pengarsipan e-pajak sebagai cabang dari e-government untuk meningkatkan pengumpulan pajak yang efisien (Abdul-jabbar, 2016).

E-filling memiliki tujuan untuk memudahkan wajib pajak dan petugas pajak dalam proses pendaftaran, dan pelaporan kewajiban pajak, sehingga memberikan kenyamanan dan kerahasiaan data pajak. Kemudahan ini juga akan dirasakan oleh pihak yang memungut pajak dalam hal ini DJP dalam proses administrasi pajak WPOP. Manfaatnya bagi wajib pajak adalah e-filling menawarkan kemudahan, tidak membutuhkan waktu lama, meminimalisir kesalahan dalam penghitungan pengembalian pajak, dan mereka dapat mengisi laporan pajak sesuai keinginan mereka. Sistem online ini memberikan banyak kemudahan seperti, fleksibilitas waktu pengajuan, menghemat tempat pengarsipan dokumen, mudah dalam mencari informasi, dan transaksi yang dilakukan secara online hyang tentu saja tidak dapat dilakukan secara manual. Berbagai kemudahan tersebut menjadi faktor pendorong penerapan e-filling (Kamarulzaman \& Azmi, 2010).

E-filling adalah hal baru dan metode efektif pengajuan pajak penghasilan online dan memiliki pajak elektronik. Keuntungan utama dari pengarsipan elektronik termasuk kemudahan penggunaan, teknologi, pengurangan terburuburu dan menghemat waktu. Setelah menggunakan layanan elektronik melalui internet, publik mungkin mendapati bahwa sistem layanan elektronik itu mudah dan bermanfaat (Kumar, 2017). Faktor-faktor yang mempengaruhi kepatuhan pajak, di bawah dua judul sebagai individu dan lingkunganfaktor-faktor. Faktor individu terdiri dari: kemampuan membayar pajak, pajak moral, loyalitas kepada pemerintah, untuk mengadopsi statuskekuatan politik, pemikiran pembayar pajak tentang orang lain (pembayar pajak), kesesuaian antara layanan publik dan pilihan wajib pajak, penggunaan pendapatan publik yang efektif dan faktor-faktor demografis (İpek \& Özkaya, 2012).

Ekspektasi usaha menunjukkan bagaimana usaha wajib pajak dalam jangka panjang. Keyakinan akan manfaat $e$-filling yang mampu mempermudah usaha, menarik wajib pajak untuk menggunakannya. Diperlukan pemahaman yang cukup terkait tata cara pengoperasian dan penggunaan e-filling. Sejauh mana pengguna mengharapkan bahwa sistem tertentu dapat membantunya untuk mendapatkan manfaat. Manfaat-manfaat ini mungkin terkait dengan keseluruhan kinerja pekerjaan. Faktor ini membantu dalam memprediksi niat perilaku dalam situasi pemanfaatan wajib dan opsional (Morris et al., 2003). Ekspektasi usahaadalah sejauh mana pengguna mengharapkan bahwa sistem tertentu dapat membantunya untuk mendapatkan manfaat. Manfaat-manfaat ini mungkin terkait dengan keseluruhan kinerja pekerjaan. Faktor ini membantu dalam memprediksi niat perilaku dalam situasi pemanfaatan wajib dan opsional.

$\mathrm{H}_{1}$ : Ekspektasi usaha berpengaruh positif pada kepatuhan wajib pajak orang pribadi di KPP Pratama Gianyar. 
Teori atribusi menyatakan bahwa pengetahuan berada di luar diri seseorang yang dapat mempengaruhi wajib pajak untuk mematuhi maupun tidak ketentuan pajak yang berlaku. Pengetahuan pajak merupakan informasi yang dimiliki wajib pajak terkait perpajakan, mulai dari ketentuannya, sanksi, proses perpajakan, dan sebagainya. Pengetahuan pajak mencakup informasi perpajakan yang dimiliki wajib pajak (Hasseldine et al., 2009). Penelitian yang dilakukan Saad, (2014) memperoleh hasil bahwa pengetahuan pengguna berpengaruh pada kepatuhan.

$\mathrm{H}_{2}$ : Pengetahuan pengguna berpengaruh positif pada kepatuhan wajib pajak di KPP Pratama Gianyar.

Keamanan dan kerahasiaan data dewasa ini menjadi suatu keharusan bagi wajib pajak. Data mengenai usaha yang dijalankan serta penghasilan yang diperoleh wajib untuk memiliki jaminan kerahasiaannya, sebab beberapa wajib pajak merasa informasi mereka tidak untuk dikonsumsi pihak lain yang tdiak berkepentingan. Keamanan data tercermin dari ditutupnya seluruh akses ke sistem yang hanya memungkinkan pengguna dan petugas yang berkewajiban dalam hal tersebut saja yang mampu mengaksesnya. E-filliing tentunya akan menjadi favorit bagi WPOP apabila mereka yakin bahwa penerapannya dapat menjaga keamanaan serta kerahasiaan informasi pribadi miliknya. Penerapan $e-$ filling dipengaruhi secara positif oleh kemananan dan kerahasiaan data seperti hasil penelitian dari (Hani \& Fitri Apriani, 2016).

$\mathrm{H}_{3}$ : Keamanan pengguna berpengaruh postif pada minat penggunaan $e$-filling di KPP Pratama Gianyar.

Waktu kini menjadi kebutuhan pokok setiap orang. Semakin sulit mencari waktu senggang ketika orang-orang sibuk tenggelam pada pekerjaannya masingmasing. Pelaporan SPT yang manual sangatlah menyita waktu yang cukup banyak, membuat orang enggan untuk melaporkan pajaknya. Oleh karena itu, kecepatan proses menjadi hal penting untuk diperhatikan DJP. E-filling menjadi solusi dari masalah tersebut. Sistem yang tidak menuntut wajib pajak untuk datang langsung ke DJP dan dapat dikerjakan dimana saja serta kapan saja akan meningkatkan keinginan wajib pajak melaporkan pajaknya. E-filling menjadi pilihan yang tepat bagi wajib pajak yang tidak memiliki banyak waktu dalam setiap harinya.

$\mathrm{H}_{4}$ : Kecepatan pelaporan berpengaruh postif pada minat penggunaan e-filling di KPP Pratama Gianyar.

E-filling merupakan sebuah sistem sebagai tempat bagi wajib pajak untuk mengaksesnya dengan username dan kata sandi pribadi, yang dapat memberikan informasi dan mengakses subsistem lain untuk kebutuhan perpajakan lainnya (Alla, 2014). Direktorat Jenderal Pajak berharap dengan adanya sistem ini dapat meningkatkan kepatuhan wajib pajak, karena e-filling menyediakan segala kemudahan dalam bertransaksi pajak bagi wajib pajak. Kepatuhan wajib pajak dalam melaksanakan kewajiban pajaknya hendaknya mampu meningkatkan minat mereka untuk menggunakan $e$-filling yang telah dirancang sedemikian rupa untuk memudahkan WPOP.

$\mathrm{H}_{5}$ : Kepatuhan berpengaruh postif pada minat penggunaan e-filling di KPP Pratama Gianyar. 


\section{METODE PENELITIAN}

Teori UTAUT merupakan teori utama yang menjadi dasar dalam penelitian ini. Penelitian dilakukan pada wajib pajak yang terdaftar di KPP Pratama Gianyar. Adapun desain penelitian dalam penelitian ini adalah sebagai berikut.

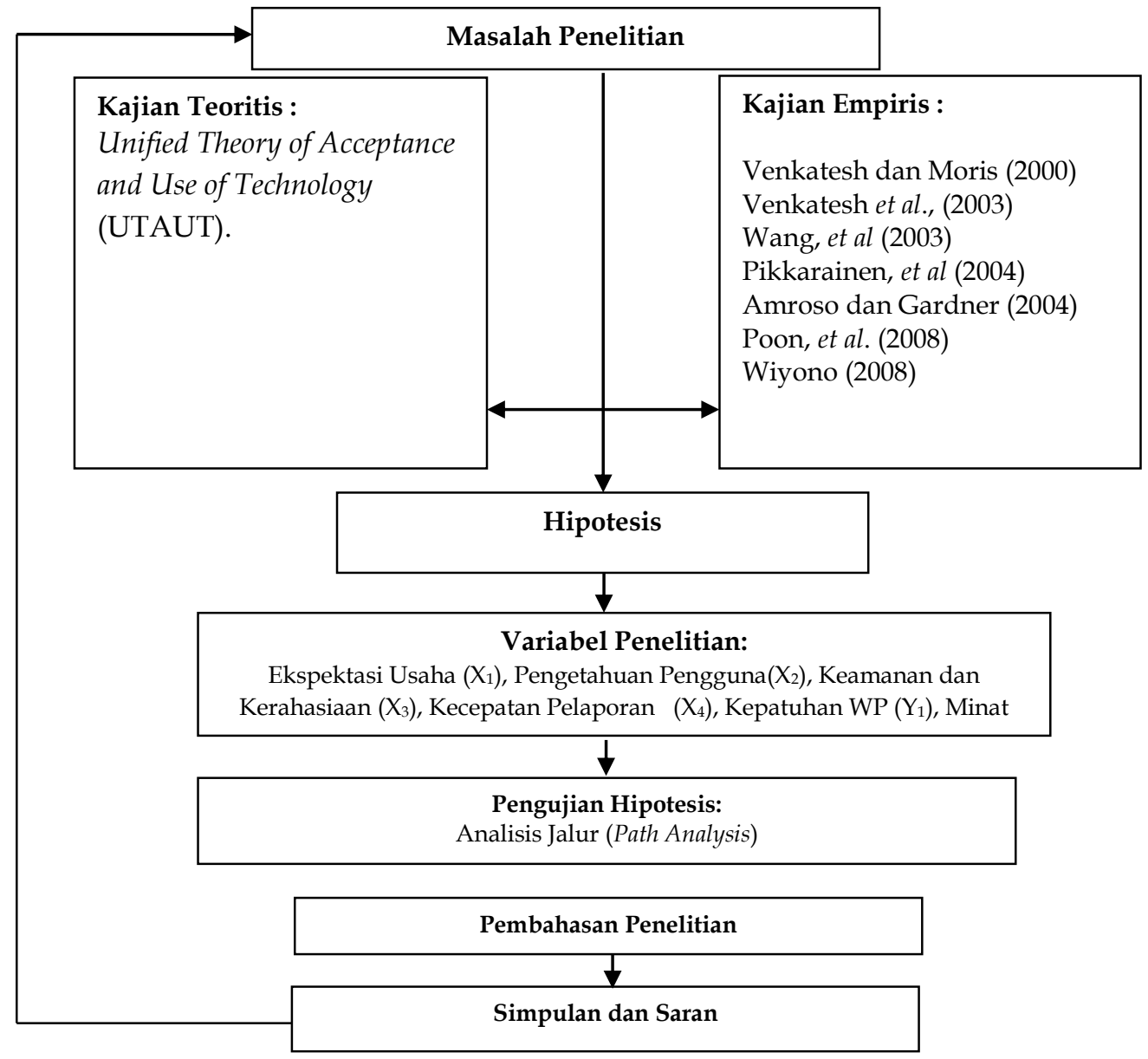

Sumber: Data Penelitian, 2019

\section{Gambar 1. Konsep Penelitian}

Terdapat 123.797 wajib pajak yang telah terdaftar dan menggunakan $e$-filling di KPP Pratama Gianyar pada tahun 2017. Penentuan sampel menggunakan rumus slovin sampel berikut.

$$
\begin{aligned}
& \mathrm{n}=\frac{N}{\left(1+N e^{2}\right)} \text {. } \\
& \mathrm{n}=\frac{123.797}{\left(1+123.797 .(0.1)^{2}\right)}
\end{aligned}
$$

n= 99.91 dibulatkan menjadi 100

Sampel diambil menggunakan metode accidental sampling yang menentukan sampel secara acak oleh peneliti. Data dikumpulkan dengan mtode survey melalui kuesioner yang diberikan oleh peneliti kepada wajib pajak yang datang ke KPP Pratama Gianyar. Kuesioner yang peneliti gunakan terdiri atas 5 pilihan jawaban skala likert. Hipotesis dalam penelitian ini diuji menggunakan Analisis Jalur (Path Analysis). Analisis Jalur merupakan perkembangan dari analisis regresi linear 
berganda yang lebih luas cakupannya, dimana analisis jalur ini memberikan penafsiran terkait hubungan kausalitas antar variabel.

Analisis ini tidak dapart menentukan hubungan antar variabel. Hubungan kausalitas yang diteliti dengan analisis jalur sebelumnya telah ditentukan oleh teori yang berkembang. Analisis Jalur memberikan penjelasan mengenai pola dari hubungan yang dibentuk oleh variabel-variabel dalam teori, namun tidak dapat memberikan konfirmasi untuk menerima atau menolak hipotesis kausalitas imajiner. Gambar di bawah ini menunjukkan model regresi linear berganda yang dikembangkan dalam penelitian ini.

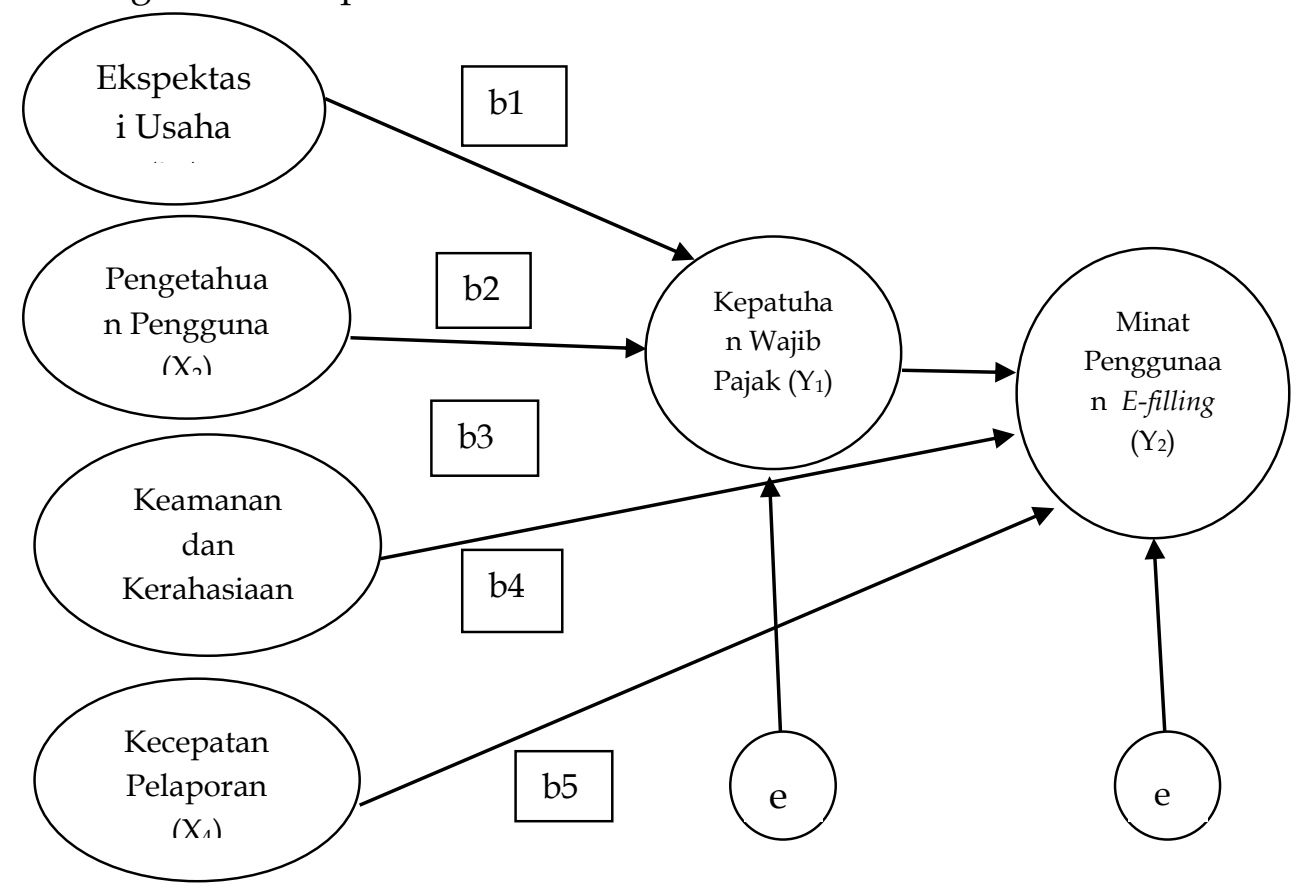

Gambar 2. Model Analisis Jalur (Path Analysis)

Sumber: Data Penelitian, 2019

Berdasarkan Gambar 2 menunjukkan bahwa anak panah b1 dan b2 menuju pada variabel kepatuhan wajib pajak (Y1) menunjukkan pengaruh langsung antara X1 dan X2 terhadap $\mathrm{Y} 1$, dan anak panah b3, b4, dan b5 menuju pada variabel minat penggunaan $e$-filling $(\mathrm{Y} 2)$ menunjukkan pengaruh langsung antara X3, X4, dan Y1 terhadap Y2 (Suyana Utama, 2014).

Struktur I : $Y 1=b_{1} X_{1}+b_{2} X_{2}+e_{1}$

Struktur II : $Y 2=b_{3} X_{3}+b_{4} X_{4}+b_{5} Y_{1}+e_{2}$

\section{HASIL DAN PEMBAHASAN}

KPP Pratama Gianyar menjadi perpanjangan tangan pihak DJP untuk memberikan pelayanan perpajakan kepada wajib pajak, baik wajib pajak orang pribadi maupun badan, yang juga memiliki tanggung jawab langsung terhadap Kepala Kantor Wilayah Direktorat Jenderal Pajak di Bali. KPP Pratama Gianyar bertanggung jawab pada 4 kabupaten di Provinsi Bali, yakni Kabupaten Gianyar, Kabupaten Bangli, Kabupaten Klungkung, dan Kabupaten Karangasem. 
Peneliti menyebarkan kuesioner di KPP Pratama Gianyar dengan metode accidental, dengan responden yaitu wajib pajak yang terdaftar dan menggunakan e-filling.

Informasi mengenai penyebaran dan pengembalian kuesioner disajjikan dalam tabel berikut.

\section{Tabel 2. Tingkat Pengembalian Kuesioner}

\begin{tabular}{lcc}
\hline \multicolumn{1}{c}{ Keterangan } & Jumlah & Persentase (\%) \\
\hline Kuesioner yang dibagikan & 100 & $100 \%$ \\
Kuesioner yang tidakdiisi & 0 & $0 \%$ \\
Kuesioner yang tidakdiisidenganlengkap & 0 & $0 \%$ \\
Kuesioner yang dapat diolah & 100 & $100 \%$ \\
Tingkat pengembaliankuesioner (respon rate) & 100 & $100 \%$ \\
Kuesioner yang digunakan (useable respon rate) & 100 & $100 \%$ \\
\hline
\end{tabular}
Sumber : Data Penelitian, 2019

Kuesioner yang disebarkan peneliti berjumlah 100 eksemplar dan kembali dengan jumlah 100 pula. Ini berarti bahwa semua kuesioner kembali, dan semua kuesioner memenuhi persyaratan sehingga tidak ada yang gugur.

Statistik deskriptif menentukan peringkat dari data yang akan digunakan dalam penelitian terkait karakteristik masing-masing data tersebut.

Tabel 3. Statistik Deskriptif

\begin{tabular}{lcccccc}
\hline \multicolumn{1}{c}{ Variabel } & $\begin{array}{c}\text { Item } \\
\text { Pertanyaan }\end{array}$ & $\mathrm{N}$ & Minimum & $\begin{array}{c}\text { Maximu } \\
\mathrm{m}\end{array}$ & Mean & $\begin{array}{c}\text { Std. } \\
\text { Deviasi }\end{array}$ \\
\hline $\begin{array}{l}\text { Ekspektasi Usaha } \\
\left(\mathrm{X}_{1}\right)\end{array}$ & $\mathrm{X}_{1.1}$ & 100 & 2 & 5 & 3,97 & 1,01956 \\
& $\mathrm{X}_{1.2}$ & 100 & 2 & 5 & 3,97 & 1,00960 \\
& $\mathrm{X}_{1.3}$ & 100 & 2 & 5 & 3,87 & 1,06035 \\
& $\mathrm{X}_{1.4}$ & 100 & 2 & 5 & 3,92 & 1,11627 \\
$\begin{array}{l}\text { Pengetahuan } \\
\text { Pengguna (X2) }\end{array}$ & $\mathrm{X}_{2.1}$ & 100 & 2 & 5 & 4,11 & 1,03372 \\
& $\mathrm{X}_{2.2}$ & 100 & 2 & 5 & 3,84 & 1,09839 \\
& $\mathrm{X}_{2.3}$ & 100 & 2 & 5 & 3,91 &, 99590 \\
$\begin{array}{l}\text { Keamanan dan } \\
\text { Kerahasiaan (X3) }\end{array}$ & $\mathrm{X}_{3.1}$ & 100 & 2 & 5 & 3,99 & 1,07774 \\
& $\mathrm{X}_{3.2}$ & 100 & 2 & 5 & 4,03 & 1,11423 \\
& $\mathrm{X}_{3.3}$ & 100 & 2 & 5 & 3,93 & 1,04693 \\
& $\mathrm{X}_{4.1}$ & 100 & 2 & 5 & 4,05 & 1,10440 \\
$\begin{array}{l}\text { Kecepatan } \\
\text { Pelaporan (X4) }\end{array}$ & $\mathrm{X}_{4.2}$ & 100 & 2 & 5 & 3,91 & 1,07398 \\
& & & & & &
\end{tabular}

Bersambung ... 
Lanjutan Tabel 3.

\begin{tabular}{lcccccc}
\hline & $\mathrm{X}_{4.3}$ & 100 & 2 & 5 & 4,00 & 1,04447 \\
$\begin{array}{l}\text { Kepatuhan Wajib } \\
\text { Pajak (Y1) }\end{array}$ & $\mathrm{Y}_{1.1}$ & 100 & 2 & 5 & 3,94 & 1,02317 \\
& $\mathrm{Y}_{1.2}$ & 100 & 2 & 5 & 4,00 & 1,04447 \\
& $\mathrm{Y}_{1.3}$ & 100 & 2 & 5 & 3,97 & 1,04886 \\
& $\mathrm{Y}_{1.4}$ & 100 & 2 & 5 & 3,80 &, 92113 \\
$\begin{array}{l}\text { Minat Pengunaan } \\
\text { E-Filling(Y2) }\end{array}$ & $\mathrm{Y}_{2.1}$ & 100 & 2 & 5 & 3,98 &, 97421 \\
& $\mathrm{Y}_{2.2}$ & 100 & 2 & 5 & 3,98 & 1,05390 \\
& $\mathrm{Y}_{2.3}$ & 100 & 2 & 5 & 3,94 & 1,02317 \\
\hline
\end{tabular}

Sumber : Data Penelitian, 2019

Keempat variabel dalam penelitian ini menunjukkan angka yang mendekati nilai tertinggi. Variabel ekspektasi usaha menunjukkan nilai mendekati nilai tertinggi, begitupula variabel pengetahuan pengguna yang menunjukkan bahwa ekspektasi usaha dan pengetahuan wajib pajak memberikan pengaruh yang baik. Variabel keamanan dan kerahasiaan data, kecepatan pelaporan, kepatuhan, dan minat wajib pajak mengguhnakan e-filling sama-sama menunjukkan nilai mendekati nilai tertinggi yang menunjukkan bahwa variabel-variabel tersebut menunjukkan pengaruh yang baik.

Kuesioner yang baik setidaknya lulus uji validitas dan reliabilitas untuk menentukan kelayakannya dalam menjadi sumber data. Validitas data setidaknya memiliki nilai Correlated Item - Total Correlation di atas 0,30.

Tabel 4. Hasil Uji Validitas

\begin{tabular}{cccc}
\hline Variabel & Indikator & Pearson Correlation & Keterangan \\
\hline \multirow{2}{*}{ Ekspektasi Usaha $\left(\mathrm{X}_{1}\right)$} & X1.1 & 0,924 & Valid \\
& X1.2 & 0,939 & Valid \\
& X1.3 & 0,916 & Valid \\
& X1.4 & 0,937 & Valid \\
Pengetahuan Pengguna $\left(\mathrm{X}_{2}\right)$ & X2.1 & 0,913 & Valid \\
& X2.2 & 0,937 & Valid \\
& X2.3 & 0,956 & Valid \\
& X3.1 & 0,922 & Valid \\
Keamanan dan & X3.2 & 0,891 & Valid \\
Kerahasiaan $\left(\mathrm{X}_{3}\right)$ & X3.3 & 0,982 & Valid \\
& & & \\
Kecepatan Pelaporan $\left(\mathrm{X}_{4}\right)$ & X4.1 & 0,945 & Valid \\
& X4.2 & 0,948 & Valid \\
Kepatuhan Wajib Pajak $\left(\mathrm{Y}_{1}\right)$ & X4.3 & 0,932 & Valid \\
& Y.1 & 0,865 & Valid \\
& Y.3 & 0,921 & Valid \\
& Y.4 & 0,922 & Valid \\
& & 0,922 & Valid \\
\hline
\end{tabular}

Bersambung ... 
Lanjutan Tabel 4.

\begin{tabular}{cccc}
\hline $\begin{array}{c}\text { Minat Penggunaan } E- \\
\text { Filling }\left(\mathrm{Y}_{2}\right)\end{array}$ & Y.1 & 0,952 & Valid \\
& Y.2 & 0,963 & Valid \\
& Y.3 & 0,929 & Valid \\
\hline
\end{tabular}

Sumber : Data Penelitian, 2019

Uji reliabilitas digunakan untuk menilai tingkat konsistensi dari pertanyaan dalam kuesioner, sehingga pertanyaan tersebut dapat digunakan sebagai variabel yang layak dalam penelitian, meskipun pertanyaan tersebut digunakan untuk menguji penelitian secara berulang-ulang. Reliabilitas data dilihat dari nilai Cronbach Alpha yang harus bernilai $>0,60$ sebagai berikut.

Tabel 5. Hasil Uji Reliabilitas

\begin{tabular}{lcc}
\hline \multicolumn{1}{c}{ Variabel } & Cronbach's Alpha & Keterangan \\
\hline Ekspektasi Usaha (X1) & 0,946 & Reliabel \\
Pengetahuan Pengguna (X2) & 0,927 & Reliabel \\
Keamanan dan Kerahasiaan (X3) & 0,924 & Reliabel \\
Kecepatan Pelaporan (X4) & 0,935 & Reliabel \\
Kepatuhan Wajib Pajak (Y) & 0,929 & Reliabel \\
Minat Penggunaan E-filling $\left(\mathrm{Y}_{2}\right)$ & 0,943 & Reliabel \\
\hline
\end{tabular}

Sumber : Data Penelitian, 2019

Uji asumsi klasik dilakukan sebelum melakukan uji atas pengaruh antar variabel, dimana setiap data harus memenuhi persyaratan semua bagian dari uji asumsi klasik. Uji normalitas merupakan uji pertama yang memiliki syarat lulus yaitu nilai signifikansi harus sama atau di atas 0,05 , yang menyatakan bahwa data berdistribusi normal.

Tabel 6. Hasil Uji Normalitas Model 1 Unstandardized Residual

\begin{tabular}{ll} 
Kolmogorov-Smirnov Z & 0,084 \\
Asymp. Sig. (2-tailed) & 0,082 \\
\hline
\end{tabular}
Sumber : Data Penelitian, 2019

Berdasarkan tabel 6 dengan melakukan uji kolmogrov-smirnov dibantu oleh progam SPSS, diketahui nilai signifikansi sebesar 0,082 > 0,05. Hal ini berarti model pertama berdistribusi normal, sehingga model layak untuk dijadikan model dalam penelitian ini.

Tabel 7. Hasil Uji Normalitas Model 2

\begin{tabular}{lcc}
\hline & Unstandardized Residual \\
\hline & 100 \\
Kolmogorov-Smirnov Z & 0,086 \\
Asymp. Sig. (2-tailed) & 0,065 \\
\hline
\end{tabular}
Sumber : Data Penelitian, 2019

Berdasarkan tabel 7 diketahui nilai signifikansi pada model regresi yang kedua sebesar 0,065 >0,05. Hal ini berarti model kedua berdistribusi normal, sehingga model kedua ini juga layak untuk dijadikan sebagai model penelitian yang hasilnya juga mampu dipertanggungjawabkan. 
Tabel 8. Hasil Uji Multikolinearitas Model 1

\begin{tabular}{ccc}
\hline \multirow{2}{*}{ Model } & \multicolumn{2}{c}{ Colinearity Statistic } \\
\cline { 2 - 3 } & Tolerance & VIF \\
\hline X1 & 0,564 & 1,772 \\
X2 & 0,564 & 1,772 \\
\hline
\end{tabular}

Sumber : Data Penelitian, 2019

Tabel 8 menunjukkan bahwa variabel $\mathrm{X} 1$ dan $\mathrm{X} 2$ memiliki nilai tolerance lebih dari 0,01, dan nilai VIF kurang dari 10, sehingga kedua variabel tersebut dapat dikatakan lolos uji multikoliniearitas.

Tabel 9. hasil uji multikolinearitas model 2

\begin{tabular}{lll}
\hline \multirow{2}{*}{ Model } & \multicolumn{2}{c}{ Colinearity Statistic } \\
\cline { 2 - 3 } & Tolerance & VIF \\
\hline X3 & 0,432 & 2,313 \\
X4 & 0,446 & 2,242 \\
Y1 & 0,490 & 2,040 \\
\hline
\end{tabular}

Sumber : Data Penelitian, 2019

Tabel 9 menunjukkan bahwa ketiga variabel telah lulus uji multikolinearitas sesuai dengan yang disyaratkan, dimana variabel X3 memiliki nilai tolerance 0,432 lebih dari 0,1 dan nilai VIF kurang dari 10 yaitu 2,313. Variabel X4 memiliki nilai tolerance 0,446 lebih dari 0,1 dan nilai VIF kurang dari 10 yaitu 2,242. Variabel Y1 memiliki nilai tolerance sebesar 0,490 lebih dari 0,1 dan VIF kurang dari 10 yaitu 2,040.

Tabel 10. Hasil Uji Heteroskedastisitas Model 1

\begin{tabular}{ccc}
\hline Model & Sig. & Keterangan \\
\hline X1 & 0,216 & Lolos Uji \\
X2 & 0,626 & Lolos Uji \\
\hline
\end{tabular}

Sumber : Data Penelitian, 2019

Berdasarkan Tabel 10 diatas menunjukkan bahwa nilai signifikansi masing-masing variabel diatas 0,05 sehingga dapat disimpulkan bahwa model pertama dalam penelitian ini bebas dari gejala heteroskedastisitas.

Tabel 11. Hasil Uji Heteroskedstisitas Model 2

\begin{tabular}{ccc}
\hline Model & Sig. & Keterangan \\
\hline X3 & 0,074 & Lolos Uji \\
X4 & 0,532 & Lolos Uji \\
Y1 & 0,821 & Lolos Uji
\end{tabular}

Sumber : Data Penelitian, 2019

Berdasarkan Tabel 11 diatas menunjukkan bahwa nilai signifikansi masing-masing variabel diatas 0,05 sehingga dapat disimpulkan bahwa model kedua dalam penelitian ini bebas dari gejala heteroskedastisitas.

Setelah data lolos dalam semua uji asumsi klasik, maka selanjutnya data diuji dengan menggunakan analisis jalur (path analysis). Hasil pengujian ditunjukkan pada dua model yang berbeda berikut. 
Tabel 12. Hasil Uji Analisis Jalur (Path Analysis) Model 1

\begin{tabular}{|c|c|c|c|c|c|}
\hline \multirow{2}{*}{ Model } & \multicolumn{2}{|c|}{$\begin{array}{l}\text { Unstandardized } \\
\text { Coefficients }\end{array}$} & \multirow{2}{*}{$\begin{array}{c}\text { Standardized } \\
\text { Coefficients } \\
\text { Beta }\end{array}$} & \multirow[b]{2}{*}{$t$} & \multirow[b]{2}{*}{ Sig. } \\
\hline & $B$ & $\begin{array}{l}\text { Std. } \\
\text { Error }\end{array}$ & & & \\
\hline Constant & 1.097 & 0.689 & & 1.592 & .115 \\
\hline Ekspektasi Usaha (X1) & .472 & .070 & .477 & 6.720 & .000 \\
\hline $\begin{array}{l}\text { Pengetahuan Pengguna } \\
(\mathrm{X} 2)\end{array}$ & .600 & .094 & .456 & 6.421 & .000 \\
\hline Adjusted $R^{2}$ & 0.718 & & & & \\
\hline F Hitung & $\begin{array}{r}127,06 \\
2\end{array}$ & & & & \\
\hline
\end{tabular}

Sumber : Data Penelitian, 2019

Berdasarkan Tabel 11 dapat dibuat rumus persamaan Analisis Jalur (Path Analysis) sebagai berikut:

Struktur I : $Y 1=0,472 b_{1} X_{1}+0,600 b_{2} X_{2}+e_{1}$

Kepatuhan wajib pajak sebagai variabel terikat akan mengalami kenaikan nilai sebesar 1,097 apabila variabel-variabel bebas dianggap memiliki nilai sama dengan nol. Variabel Ekspektasi usaha memiliki nilai koefisien beta sebesar 0,472 yang memberikan arti bahwa semakin tinggi ekspektasi usaha dari wajib pajak maka semakin tinggi pula kepatuhannya. Variabel pengetahuan juga memiliki arti yang sama, berbanding lurus dengan variabel kepatuhan karena nilai koefisien betanya sebesar 0,600 .

Tabel model 1 menunjukkan bahwa kepatuhan wajib pajak memang dipengaruhi oleh variabel-variabel bebas tersebat dengan angka mencapai 71,8 persen $(0,718)$ seperti yang terlihat pada nilai Adjusted R square. Hanya 28,2 persen yang dipengaruhi oleh faktor-faktor lain yang tidak menjadi objek dala penelitian ini.

Kedua variabel bebas diketahui memberikan pengaruh yang signifikan terhadap kepatuhan wajib pajak. Hal ini dapat kita lihat dari nilai signifkansi $\mathrm{F}$ yang kurang dari 0,05 yaitu 0,000 .

Tabel 13. Hasil Uji Analisis Jalur (Path Analysis) Model 2

\begin{tabular}{|c|c|c|c|c|c|}
\hline \multirow[t]{2}{*}{ Model } & \multicolumn{2}{|c|}{$\begin{array}{l}\text { Unstandardized } \\
\text { Coefficients }\end{array}$} & \multirow{2}{*}{$\begin{array}{c}\begin{array}{c}\text { Standardized } \\
\text { Coefficients }\end{array} \\
\text { Beta }\end{array}$} & \multirow[t]{2}{*}{$t$} & \multirow[t]{2}{*}{ Sig. } \\
\hline & $B$ & $\begin{array}{l}\text { Std. } \\
\text { Error }\end{array}$ & & & \\
\hline Constant & - & 0.387 & & - & .497 \\
\hline & 0.264 & & & 0.681 & \\
\hline $\begin{array}{l}\text { Keamanan dan kerahasiaan } \\
(\mathrm{X} 1)\end{array}$ & .348 & .057 & .350 & 6.061 & .000 \\
\hline Kecepatan Pelaporan (X2) & .407 & .057 & .402 & 7.082 & .000 \\
\hline Kepatuhan Wajib Pajak (X3) & .226 & .041 & .296 & 5.459 & .000 \\
\hline Adjusted $R^{2}$ & 0.858 & & & & \\
\hline F Hitung & 199.6 & & & & \\
\hline & 16 & & & & \\
\hline Sig. F & .000 & & & & \\
\hline
\end{tabular}

Sumber : Data Penelitian, 2019 
Berdasarkan Tabel 12 dapat dibuat rumus persamaan Analisis Jalur (Path Analysis) sebagai berikut:

$$
\mathrm{Y} 2=0,348 \mathrm{~b}_{3} \mathrm{X}_{3}+0,407 \mathrm{~b}_{4} \mathrm{X}_{4}+0,226 \mathrm{~b}_{5} \mathrm{Y}_{1}+\mathrm{e}_{2}
$$

Hasil yang berbeda kita lihat pada tabel model 2, dimana nilai minat penggunaan $e$-filling justru menurun 0,264 satuan ketika variabel keamanan dan kerahasiaan $\left(X_{3}\right)$ dan kecepatan pelaporan $\left(X_{4}\right)$ dianggap bernilaisetara dengan nol. Namun dilihat dari nilai koefisien beta variabel $X_{3}$ dengan angka 0,407 dan $X_{4}$ sebesar 0,226 tampaknya memberikan hasil yang positif, yaitu seiring dengan meningkatnya keamanan dan kerahasiaan data serta kecepatan pelaporan, maka wajib pajak akan semakin berminat untuk menggunakan $e$-filling.

Variabel terikat pada model kedua ini yaitu minat penggunaan e-filling $\left(\mathrm{Y}_{2}\right)$ terlihat dipengaruhi secara signifikan dan bersama-sama oleh ketiga variabel diantaranya keamanan dan kerahasiaan data $\left(X_{3}\right)$, kecepatan pelaporan $\left(X_{4}\right)$, dan kepatuhan wajib pajak $\left(\mathrm{Y}_{1}\right)$. Hal ini dibuktkan dengan nilai signifikansi $\mathrm{F}$ kurang dari yang disyaratkan yaitu 0,000.

Variabel ekspektasi usaha menunjukkan nilai signifikansi t sebesar 0,000 kurang dari 0,05. Nilai tersebut memperlihatkan bahwa hipotesis pertama dalam penelitian diterima, dimana ekspektasi usaha berpengaruh positif pada kepatuhan wajib pajak orang pribadi di KPP Pratama Gianyar, yang berarti lebih kecil dari nilai $\alpha=0,05$. Teori UTAUT menyatakan bahwa teknologi yang diterima maupun yang tidak oleh wajib pajak dipengaruhi secara langsung oleh ekspektasi usaha. Keyakinan wajib pajak bahwa sistem e-filling mampu membantu usahanya maka akan semakin mematuhi kewajiban pajaknya.

Variabel pengetahuan pengguna memiliki nilai signifikansi t sebesar 0,000 kurang dari 0,05 yang menunjukkan bahwa hipotesis kedua yaitu pengetahuan pengguna memiliki pengaruh positif pada kepatuhan WPOP diterima. Wajib pajak yang memiliki pengetahuan yang cukup mengenai perpajakan akan semakin patuh pada perpajakan karena mereka tau betul terkait sanksi-sanksi yang mungkin akan diperoleh apabila tidak memenuhi kewajibannya sebagai wajib pajak.

Variabel keamanan dan kerahasiaan data bernilai signifikansi t sebesar 0,000 yang juga kurang dari 0,05, berarti keamanan dan kerahasiaan data berpengaruh positif pada minat wajib pajak untuk menggunakan e-filling. Keamanan dan kerahasiaan data menjadi penting bagi wajib pajak karena terkait dengan aset serta penghasilan yang dimiliki, oleh karena itu sistem yang mampu menjamin kerahasiaan data akan sangat diminati wajib pajak. Sistem $e$-filling dapat menjaga keamanan data sehingga kecil kemungkinan risiko kehilangan data.

Variabel kecepatan pelaporan dalam penelitian ini menunjukkan hasil bahwa hipotesis keempat diterima, yaitu kecepatan pelaporan memiliki pengaruh positif pada minat wajib pajak untuk menggunakan e-filling yang dibuktikan dengan nilai signifikansi $t$ sebesar 0,000 kurang dari nilai $a=0,05$. Kecepatan membantu wajib pajak dalam menghemat waktu yang diperlukan untuk memenuhi kewajiban pajaknya. Sistem e-filling sebagai sistem online yang sangat praktis dan cepat serta mempermudah wajib pajak dan petugas perpajakan.

Variabel kepatuhan perpajakan memiliki hasil yang sama yaitu memberikan pengaruh positif pada minat penggunaan e-filling dengan nilai signifikansi $t$ sebesar 0,000 yang berarti kurang kecil dari nilai $a=0,05$. Hal ini menunjukkan 
bahwa wajib pajak yang patuh akan kewajibannya akan menggunakan e-filling sebagai sistem perpajakan yang kini digunakan oleh DJP. Kepatuhan wajib pajak akan peraturan perpajakan yang berlaku akan memaksa mereka untuk menerapkan e-filling, sebab e-filling kini telah diwajibkan untuk diimplementasikan dalam setiap transaksi perpajakan, mulai dari pelaporan hingga pembayaran pajak.

\section{SIMPULAN}

Ekspektasi usaha, pengetahuan pengguna, keamanan dan kerahasiaan serta kecepatan pelaporan merupakan faktor-faktor yang mempengaruhi kepatuhan wajib pajak dalam memenuhi kewajiban pajaknya. Wajib pajak yang memiliki keyakinan akan kemudahan dalam mengurus usahanya berkat e-filling akan menerapkan sistem tersebut dalam bertransaksi perpajakan. Pengetahuan perpajakan yang dimiliki wajib pajak dapat mendorong kepatuhan pajaknya, sebab mereka mengerti akan sanksi yang mungkin akan diperoleh. Keamanan dan kerahasiaan data juga tak kalah pentingnya. Data perpajakan merupakan hal rahasia dan sangat dibutuhkan keamanan untuk segala informasi wajib pajak. Sistem e-filling sebagai portal online menyimpan informasi pengguna dengan sangat baik dan mustahil untuk diketahui oleh orang yang tidak bersangkutan. Hal tersebut dapat meningkatkan kepatuhannya dan minat dalam menerapkan sistem tersebut. Wajib pajak terkadang enggan mematuhi perpajakan dikarenakan waktu yang sangat lama dalam prosesnya yang dilakukan secara manual. Melalui sistem ini, semua dapat dikerjakan dengan cepat dan fleksibel untuk masalah waktu dan tempat yang tentunya hal ini sangat mempermudah wajib pajak dan mampu meningkatkan keinginan mereka untuk membayar pajaknya. Sosialisasi mengenai e-filling baik itu cara kerja, penggunaan, serta informasi-informasi terkait wajib untuk dilakukan oleh KPP Pratama Gianyar yang dapat memberikan pengetahuan lebih bagi wajib pajak sehingga mampu meningkatkan keinginan mereka dalam menerapkan sistem ini. Direktorat Jenderal Pajak berperan penting dalam menjamin kenyamanan dan memberikan pelayanan terbaik kepada wajib pajak untuk menarik minat mereka dalam mematuhi kewajibannya.

\section{REFERENSI}

Abdul-jabbar, H. (2016). Electronic Tax Filing Adoption and its Impact on Tax Employees Performance in Jordan: A Proposed Framework Electronic Tax Filing Adoption and its Impact on Tax Employees Performance in Jordan : A Proposed Framework. World Applied Sciences Journal, 34(3), 393-399. https://doi.org/10.5829/idosi.wasj.2016.34.3.15671

Alla, M. (2014). The System of Tax filing in Albania , "E-filing ". International Journal of Science and Technology, 3(9), 501-507.

Attuquayefio, S. N. (2014). Using the UTAUT model to analyze students ' ICT adoption Samuel NiiBoi Attuquayefio Methodist University College , Ghana Hillar Addo University of Professional Studies, Ghana. International Journal of Education and Development, 10(3), 75-86.

Deyganto, K. O. (2018). Factors Influencing Taxpayers' Voluntary Compliance Attitude with Tax System : Evidence from Gedeo Zone of. Universal Journal of Accounting and Finance, 6(3), 92-107. 
https://doi.org/10.13189/ujaf.2018.060302

Febrianti, T. Y. (2014). Pengetahuan Perpajakan dan Kesadaran Pajak terhadap Kepatuhan Wajib Pajak Orang Pribadi.

Handayani, R. (2007). Analisis Faktor-Faktor yang Mempengaruhi Minat Pemanfaatan Sistem Informasi dan Penggunaan Sistem Informasi ( Studi Empiris Pada Perusahaan Manufaktur di Bursa Efek Jakarta ). Jurnal Akuntansi Dan Keuangan, 9(2), 76-88.

Handoyo, S., \& Candrapuspa, H. M. (2017). Knowledge of Fraud and Taxpayer Compliance. Journal of Economics and Policy, 10(1), 385-397.

Hani, S., \& Fitri Apriani. (2016). Faktor- Faktor yang Mempengaruhi Perilaku Wajib Pajak Orang Pribadi terhadap Penggunaan E-filling. Jurnal Akuntansi, Keuangan E Perpajakan, 03(01), 83-97.

İpek, S., \& Özkaya, S. (2012). Considerations of Taxpayers According to Situation of Benefiting From Tax Amnesty: An Empirical Research Department of Public Finance. International Journal of Business and Social Science, 3(13), 95-101.

Kamarulzaman, Y., \& Azmi, A. A. C. (2010). Tax E-filing Adoption in Malaysia : A Conceptual Model. Journal of E-Government Studies and Best Practices, 2010, 16.

Komala, Kirana Cipta., D. (2014). Pengaruh Kualitas Pelayanan Perpajakan terhadap Kepatuhan Wajib Pajak Badan (Studi pada Kantor Pelayanan Pajak Madya Malang). PS Perpajakan, 2(1), 1-9.

Kumar, S. (2017). A Study On Income Tax Payers Perception Towards Electronic Filling. Journal of Internet Banking and Commerce, 22(S7), 1-14.

Mahestyanti, P., Juanda, B., \& Anggraeni, L. (2018). The Determinants of Tax Compliance in Tax Amnesty Programs: Experimental Approach. Jurnal Etikonomi, 17(1), 93-110.

Manual, V., \& Xin, A. Z. (2016). Impact of Tax Knowledge, Tax Compliance Cost, Tax Deterrent Tax Measures towards Tax Compliance Behavior : A survey on Self-Employed Taxpayers in West Malaysia. Electronic Journal of Business and Management, 1(1), 56-70.

Mareta., D. (2014). Pengaruh Pelaksanaan Sensus Pajak Nasional, Kualitas Pelayanan dan Pengetahuan terhadap Kepatuhan Wajib Pajak (Studi pada Wajib Pajak Orang Pribadi di KPP Pratama Batu). Jurnal Administrasi Bisnis, $1-7$.

Marjan, R. M. (2014). Pengaruh Kesadaran Wajib Pajak, Pelayanan Fiskus, dan Sanksi Pajak terhadap Tingkat Kepatuhan Formal Wajib Pajak (Studi di Kantor Pelayanan Pajak Pratama Makassar Selatan). Skripsi Jurusan Akuntansi Fakultas Ekonomi dan Bisnis Universitas Hasanuddin.

Morris, M. G., Hall, M., Davis, G. B., Davis, F. D., \& Walton, S. M. (2003). User Acceptance of Information Technology: Toward A Unified View. MIS Quarterly, 27(3), 425-478.

Mukisa, M. T., \& Ochieng, D. O. (2013). Council for Innovative Research. International Journal of Management $\mathcal{E}$ Information Technology, 5(3), 614-628.

Muthulakshmi, K. S. K. (2019). E-Filing of Income Tax Return: A Study on Awareness and Satisfaction Level of Tax Payers in Trichy City E-Filing of Income Tax Return: A Study on Awareness and Satisfaction Level of Tax Payers in Trichy City. International Journal for Scientific Research \& Development, 
5(9), 269-272.

Noviandini, N. C. (2012). Pengaruh Persepsi Kebermanfaatan, Persepsi Kemudahan, dan Kepuasan Wajib Pajak terhadap Penggunaan E-Filling bagi Wajib Pajak di Yogyakarta. Jurnal Nominal, I(1), 15-22.

Ramayah, T. \& M. J. (2010). Technology Acceptance: An Inidividual Perspective Current and Future Research in Malaysia. Centre of Policy Research, (1999).

Saad, N. (2014). Tax Knowledge, Tax Complexity and Tax Compliance : Taxpayers ' View. Procedia - Social and Behavioral Sciences, 109(1), 1069-1075. https:// doi.org/10.1016/j.sbspro.2013.12.590

Tene, J. H. (2017). Pengaruh Pemahaman Wajib Pajak, Kesadaran Pajak, Sanksi Perpajakan dan Pelayanan Fiskus terhadap Kepatuhan Wajib Pajak. Jurnal EMBA, 5(2), 443-453.

Wiyono, A. S. (2008). Evaluasi Prilaku Penerimaan Wajib Pajak terhadap Penggunaan E-Filling sebagai Sarana Pelaporan Pajak Secara Online dan Realtime. Jurnal Riset Akuntansi Indonesia, 11(117-132).

$\mathrm{Yu}$, O. H.-B. C. (2018). Success factors in e-channels: The Malaysian banking scenario International Journal of Bank Marketing Article information: International Journal of Bank Marketing, 21(6), 369-377. https://doi.org/10.1108/02652320310498519 